Received 19.07.2016

Reviewed 24.10.2016

Accepted 21.11.2016

A - study design

B - data collection

C - statistical analysis

D - data interpretation

$\mathbf{E}$ - manuscript preparation

F - literature search

\title{
Effectiveness and sustainability of remedial actions for land restoration in Abeokuta urban communities, Ogun state, Nigeria in Abeokuta urban communities,
}

\author{
Okanlade Adesokan LAWAL-ADEBOWALE ${ }^{\text {ABCDEF } \bowtie}$
}

Federal University of Agriculture, Department of Agricultural Extension and Rural Development, Alabata Road, P.M.B. 2240, Abeokuta, Ogun State, Nigeria; tel. +23 48034873606, e-mail: lawal-adebowaleoa@funaab.edu.ng

For citation: Lawal-Adebowale O.A. 2017. Effectiveness and sustainability of remedial actions for land restoration in Abeokuta urban communities, Ogun state, Nigeria. Journal of Water and Land Development. No. 32 p. $53-$ 61. DOI: $10.1515 /$ jwld-2017-0006.

\begin{abstract}
The destructive impact of land degradation on social and economic endeavours of the residents of certain urban areas of Abeokuta communities in Ogun State, Nigeria calls for remedial actions to restoring the affected land areas. This becomes essential in order to ensure safe inhabitation and enhanced socioeconomic engagements of the residents. Taken remedial actions in this regard included the use of sandbags, debris and wood logs, rubbles and stones, construction of contours and drainages. While each of these actions, in one way or the other, effectively improves the degraded land, it was concluded that the use of rubbles and stones, and drainage construction were sustainably durable for land restoration on the premise that these actions does not allow for water logging or flooding in of the study area. It was however recommended that these sustainable remedial actions should rather be pro-actively taken for prevention of land degradation than being taken as degraded land restoration actions basically because it is much cheaper to prevent environmental degradation than to have the degraded land restored.
\end{abstract}

Key words: causal factors, effectiveness, land degradation, remedial actions, sustainability, urban communities

\section{INTRODUCTION}

Arising from social and economic values of land to humans the natural asset has continued to face a great deal of pressures for accessibility and utilisation, especially in urban areas where there is heavy concentration of human population [World Bank 2016]. According to United Nations Environment Programme - UNEP [2002], human concentration in urban areas is engendered by the quest for better living condition arising from available opportunities and services such as job/employment provisions, education and modern healthcare services, and better living environment, in the urban areas. An instance in this regard is heavy concentration of human population in Abeokuta, a onetime ancient town in Ogun State, Ni- geria, as a result of increased social and economic opportunities, particularly in the last two decades. The increased population in turn becomes a platform for increased economic activities in the range of educational services, banking, commerce and industry, and private businesses. In the light this was United Nations Centre for Human Settlements - UNCHS [2001] indication of the existence of a strong positive link between national levels of human development and urbanisation. The urban-based provision of access to economic engagement and income generation is believed to afford inhabitants of the urban environment the opportunity to escape the grip of poverty.

This notwithstanding, human concentration and their socioeconomic engagement has greatly pressured available land space, not only beyond its natural 
carrying capacity to produce and support heavy human concentration but equally overstrain the land to the point of becoming degraded [NKONYA et al. 2011; UNCCD 2012]. This submission is premised on the observed impact of population pressure on land space in Abeokuta whereby new vegetation covers are cleared for construction of housing units, terrains, commercial and industrial centres for the purpose of fulfilling their social and economic engagement. This is however accompanied by poor land use pattern and other land-pressure exacting activities, among which are poor arrangement of housing units, non-construction or poorly constructed drainages, sand mining, compaction of terrains arising from entrenched footpaths [LAWAL-ADEBOWALE, AROMOLARAN 2015]. This land-pressure exacting activities, alongside the land gradient/slopes of the environment create the platform for runoff whenever it rains and the consequent degradation of land area of the communities. This situation goes in line with GREPERRUD [1996], SAFRIEL [2007], VlEK et al. [2008], BHANDARI [2013] attribution of increased population alongside such social and economic engagement as vegetation clearing, deforestation, soil and nutrient mining, cultivation on steep slopes, inappropriate land use and habitation pattern as causal factors of land degradation.

Land degradation of course implies loss of the inherent value of land such that it becomes either less productive or inhabitable. As further described by the International Food Policy Research Institute - IFPRI [2011], land degradation entails the loss of beneficial goods and services, such as soil, animals, vegetation and other plants, that are derivable from the terrestrial ecosystems, and the ecological and hydrological processes that operate within the systems. According to UNCCD [2012], land degradation is the reduction or loss of the biological, and/or economic productivity and complexity of cropland, range, pasture, forest and woodlands as result of both human and no-human activities. Land degradation however affects the socio-ecological and economic wellbeing of human society in various ways. According to UNCCD [2012], effects of land degradation range across food insecurity, increased poverty rate, destruction of social and cultural fabrics. Emphasising the cost implication of land degradation, IFPRI [2011] indicated that it amounts to as much as US \$ 66 billion per year and up to $10 \%$ of the national Gross Domestic Product (GDP) in the sub-Saharan Africa. In view of this, it suggests that persistent and unabated degradation of land becomes a threat not just to mankind's quest for social and economic development but to his survival and existence thereby calling for actions to combat and restore the degraded land.

Land restoration or reclamation, as described by Massachusetts Nonpoint Source Pollution Management [undated], constitutes a management practice that is associated with the process of returning damaged lands to its original condition or acceptable condition through smoothing and/or critical area planting; it is the return of lands that have been degraded by human activities or impaired by natural phenomena to its productive state or social and economic values [OECD 2007]. In essence, land reclamation calls for restoration of degraded land to its productive capacity and form such that the natural asset could productively support humans' social and economic endeavours for transformational development. In the light of this are development of series of remedial actions for land restoration around the world and among these are soil and water conservation, erection of structures for prevention of erosion or water movement, planting of trees, grass strip and other vegetation covers, proper drainage system and land scraping [JUNGE et al. 2008; NKONYA et al. 2008; USEPA 2002]. Conscientious implementation of such series of remedial actions is known to have effectively improved the value of degraded lands to the benefit of human society. In the same vein, residents of Abeokuta communities were observed to have put up certain remedial actions for restoration of degraded land in their environment. Remedial actions for land restoration in the study area however become worthwhile only when it sustainably control and restore the degraded land to its productive forms. On this note was the need to examine the pattern of land degradation, form of remedial actions employed for land restoration by the resident of Abeokuta communities and ascertain the sustainability of such remedial actions.

\section{MATERIALS AND METHODOLOGY}

Abeokuta, comprising Abeokuta and North Local Government Areas (LGAs), is the capital of Ogun State, located in Southwest part of Nigeria. The study was however conducted in Abeokuta South Local Government Area of the State which has a land area of about of $71 \mathrm{~km}^{2}$ and population size of about 250,278 as at 2006. Based on the projected population growth rate of 2.7 , the current population rate is put at 300,000 . As the core centre of the State capital, economic activities in Abeokuta South LGA include merchandising in a wide range of household goods and services, banking, educational and civil services.

The population study consists of residents of communities with degraded land and ten of such communities, namely Apete, Idi-aba, Oloruntedo, Ogunji, Obete, Ilugun, Olokuta, Asero, Araromi and Obantoko, were purposively selected as study domain based on visibility, pattern and magnitude of degraded lands in the areas. In these communities were interactions with as many individuals as were willing to give out their valuable time for provision of useful information on the issue of remedial actions for land restoration and this amounted to 173 individuals as respondents at the long run. Data for the study were qualitatively collected using Phenomenological, Inductive Thematic, and Conversation/Discourse Analyses approaches which have to do with the use of text, visual image and sounds as means of data collection 
[JONES 2014; NKWI et al. 2001]. In view of this were the use of field observation and photographic capturing for collection of images of land degradation and restoration action, use of interview and discursion to corroborate the observed field images. The observed images were qualitatively analysed by means of naming, categorisation and comparison [CORBIN, STRAUSS 2008].

\section{RESULT AND DISCUSSION}

\section{PATTERN OF LAND DEGRADATION IN THE STUDY DOMAIN}

Land degradation, as observed in the study area, takes different forms (Tab. 1) and these were land erosion, loss of land cover, soil compaction, strips of potholes, water logging and land inundation/flooding. Each of these were characterised by varying features. For instance, land erosion is highly characterised by varying degree of soil removal as a result of runoff thereby leading to wear and tear of terraces, exposure of subsoil and emergence of varying degree of land depressions. The depression takes the form of splash, rill and gullies, depending on the degree and the rate of runoff (Photo 1). According to TURKELBOOM et al. [2001], the runoff and surface erosion was observed to have been triggered not just by the volume of the rainfall but intensity of the rainfall. Consequently, the rain runoff, as indicated by ECan [2007], detaches individual soil particles as it moves along thereby creating and opening up trenches in form of tear and wear of the land surface.

Constant disturbance of land, particularly in terms of clearing for urban farming and sand scraping, leads

Table 1. Pattern of land degradation in the study domain

\begin{tabular}{|c|c|}
\hline $\begin{array}{l}\text { Types of land } \\
\text { degradation }\end{array}$ & Characteristics of degradation \\
\hline Land erosion & $\begin{array}{l}\text { varying degree of soil removal as result of run- } \\
\text { off } \\
\text { exposure of subsoil } \\
\text { emergence of varying degree of land depres- } \\
\text { sion leading to: splash, rill and gullies }\end{array}$ \\
\hline Loss of land cover & $\begin{array}{l}\text { sand scrapping } \\
\text { bareness of land as result of removal of land } \\
\text { cover } \\
\text { destroyed soil structure }\end{array}$ \\
\hline Soil compaction & $\begin{array}{l}\text { hardiness of land surface } \\
\text { emergence of land depression, } \\
\text { high rate of run-off and water logging } \\
\text { susceptible land slipping }\end{array}$ \\
\hline Strips of potholes & $\begin{array}{l}\text { scattered multiple holes over the land } \\
\text { roughness of the roads } \\
\text { development of small and temporary streams }\end{array}$ \\
\hline Water logging & $\begin{array}{l}\text { accumulation of water either in patches of land } \\
\text { depression or a large depression } \\
\text { emergence of muddy and mired land surface } \\
\text { emergence of large volume of sediment }\end{array}$ \\
\hline Flooding & $\begin{array}{l}\text { inundation of the environment by large of } \\
\text { water from erosion } \\
\text { overflowing of canals }\end{array}$ \\
\hline
\end{tabular}

Source: own elaboration.

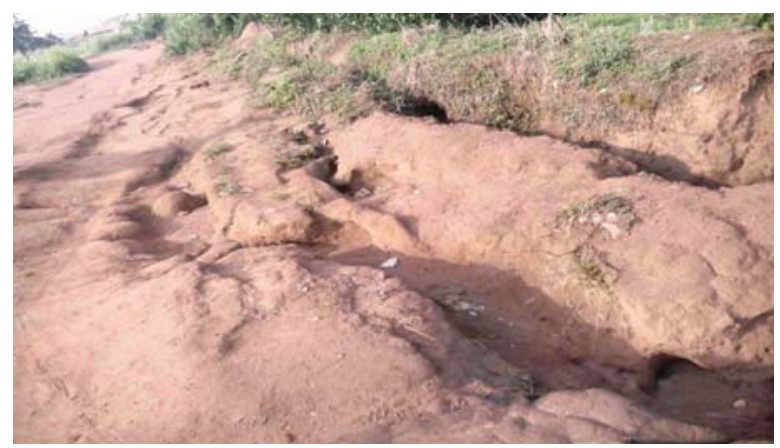

Photo 1. Degraded land area arising from erosion (phot. O.A. Lawal-Adebowale)

to loss of vegetation cover thereby leaving the land bare and making it prone to erosion, gradual and eventual destruction of the soil structure. In the light of this was FRANCIS et al. [2001] indication that repeated disturbance of top soils particularly in terms of clearing, substantially reduce soil organic matter and destruction of soil properties. According to SKOUPY [1987], MACAULAY [2014], human activities in the last 30years has brought about continuous loss of vegetation cover and as indicated by CATRO-FILHO et al. [2001] loss of land cover as a form of land degradation, constituted $70 \%$ of global land degradation.

Arising from exposure of land to nature and continuous treading of the soil surface by man and vehicles was the emergence of soil compaction in the study area. The compaction is characterised by hardiness of land surface, gradual depression or lowering of land surface, inundation with series of potholes. These destructive features thus enhanced high rate of runoff, water logging, and slippery of the land surface. These observed characteristic features, as expressed by WOLKOWSKI and LOWERY [2008], were underlined by physical consolidation of the soil by an applied force that destroys soil structures, reduces porosity, and limits water infiltration. As further emphasised by the authors, between $70 \%$ and $80 \%$ of the compaction occurs during the first pass over the field.

The emerging strips of land pores or potholes in the study area is characterised by scattered multiple pores over the land thereby leading to roughness of the roads and development of small and temporary streams (Photo 2). According to CMA [undated]; ECan [2007], such series of pore were aftermath of splash erosion whereby aggregates of soil particles are broken off into individual soil particles as a result of raindrop-impacts, thereby bringing about formation of crusts or series of 'water pots' whenever it rains and when dry resulted in roughness of the roads (Photo 2).

Further expansion and depression of the pore series were observed to have transformed to large depression for collection of a large amount of water resulting from rainfall and runoff; and due to poor or drainage system for channelling out the accumulated water, the environment becomes water logged for several days in the study area (Photo 3). This is similar to ANISHA and HoSSAIN [2014] observation of 

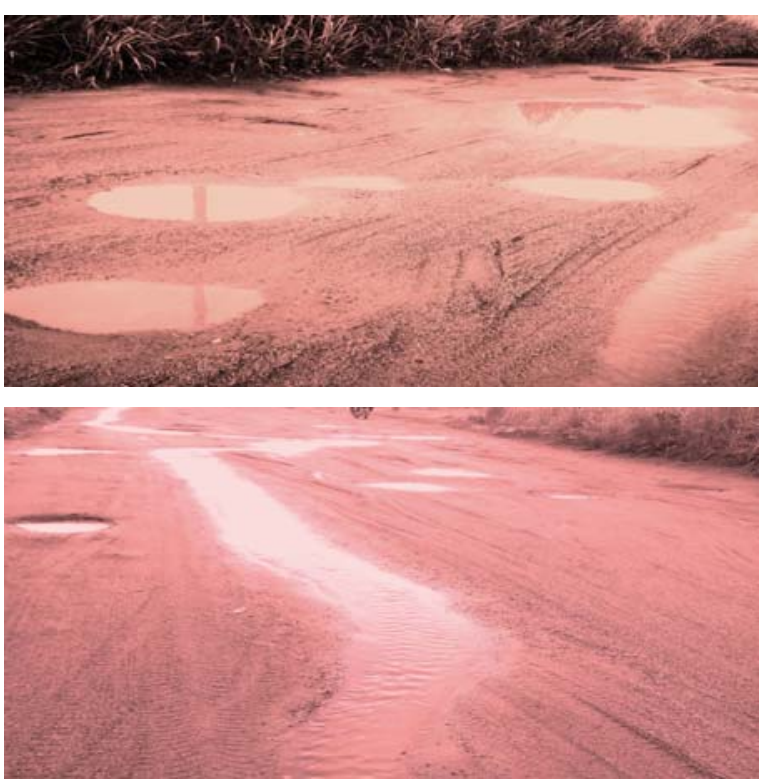

Photo 2. Scattered multiple water pores and temporary stream along the road (phot. O.A. Lawal-Adebowale)

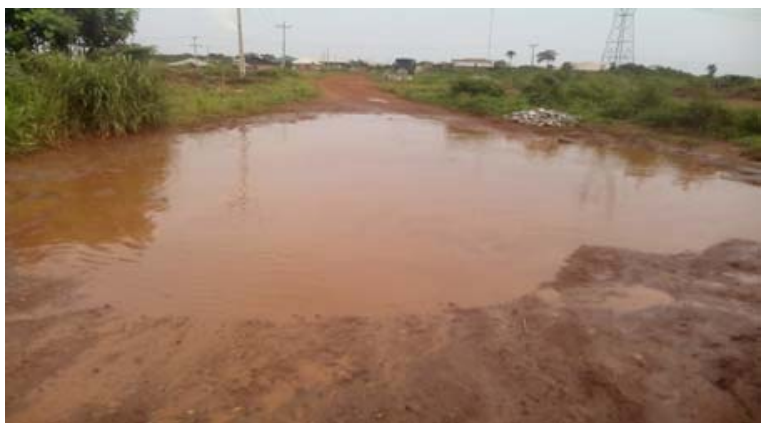

Photo 3. Water logged environment as result of lack of drainage system (phot. O.A. Lawal-Adebowale)

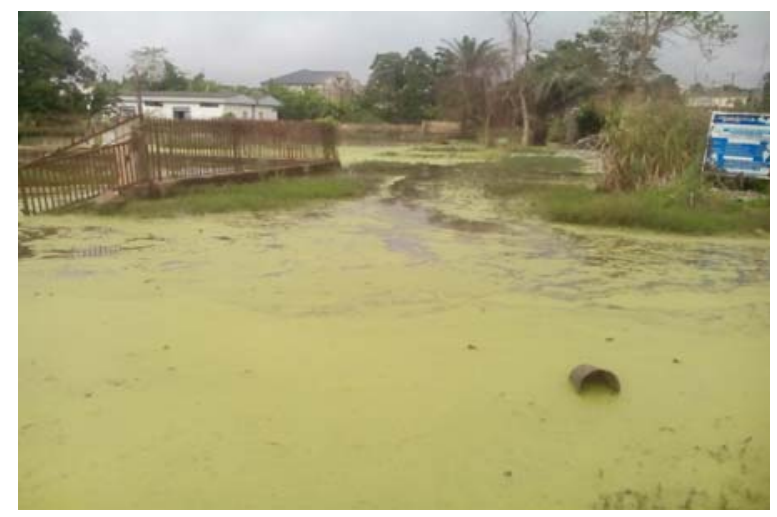

Photo 4. Stagnated floods of water turning green due to lack of drainage (phot. O.A. Lawal-Adebowale)

water logging of urban areas in Bangladesh whereby the water level remains higher than the terrain of the urban areas particularly during the monsoon. Highlighting the principles of water logging, MICHAEL and OJHA [2006] express that land becomes water logged when it becomes saturated with water with an accompanying rise in the ground water table such that the land could not permit man's anticipated activities such as habitation, construction of structures and social and economic engagements. This situation, as indicated by IDAH et al. [2009], may be permanent, temporal or seasonal, depending on the floodplain of particular areas.

Flooding, which often occur as a result of heavy rainfall and overflowing canals, makes the environment inundation with large volume of water (Photo 4). The observed floods in the study area were often sudden and usually arose from heavy and intense rainfall. Floods, as opined by The State of Queensland [2011], are though a natural process caused by heavy rainfall and overflow of the rivers, such inundations are underscored by human activities. In the light of this, field observation showed that the experienced flash floods in the study area were due to poor layout of housing units and lack of clear cut or specified water course for outflow of rain waters. As equally observed by OGBOI and NMOR [2013], houses were observed to have been built in close knits and even on water ways.

\section{EFFECTS OF LAND DEGRADATION ON THE SOCIAL LIFE OF RESIDENTS OF THE STUDY AREA}

Observation of the degraded environment and interaction with the selected residents of area showed that they were in one way or the other affected by the degraded land. Based on the responses of the surveyed residents of Abeokuta communities, as indicated by Table 2, destruction of roads and terrains were observed as the major negative effects of land degradation in the study area. Consequential effects of these, as indicated by $94.2 \%$ of the residents, were hindrances of smooth movement of humans and vehicles in the area, destruction of structures (65.3\%) such as buildings, fences, and electricity poles, decorative and economic trees, and hindrances of social and economic engagements in the environment as indicated by $79.2 \%$ of the surveyed residents. These outcomes were similar to ANISHA and HOSSAIN [2014] observation in urban environment of Dhaka, Mymensingh, Chittagongand Sylhet in Bangladesh where water logging, as a form of land degradation, not only accounted for destruction of roads, houses and households goods but caused the damage of underground service lines, water pollution, water borne diseases and increase of construction and maintenance costs.

Table 2. Effects of land degradation on the selected Abeokuta communities $(n=173)$

\begin{tabular}{|l|c|c|}
\hline \multicolumn{1}{|c|}{ Variables } & $\begin{array}{c}\text { Fre- } \\
\text { quency }\end{array}$ & $\begin{array}{c}\text { Percent- } \\
\text { age }\end{array}$ \\
\hline Destruction of roadways/terrain deformation & 173 & 100.0 \\
\hline Hindrance of mobility & 163 & 94.2 \\
\hline Destruction of structures & 113 & 65.3 \\
\hline Threats to safe habitation & 173 & 100.0 \\
\hline Hindrances of social and economic activities & 137 & 79.2 \\
\hline
\end{tabular}

Source: own elaboration. 
In the light of this was TowHID [2004] submission that, land degradation in its various forms becomes a burden to inhabitants of affected urban areas in terms of unhygienic environment and adverse social, economic and environment endangerment.

\section{REMEDIAL ACTIONS FOR LAND RESTORATION IN SELECTED URBAN ABEOKUTA COMMUNITIES}

An attempt to ameliorate the negative effects and potential danger of land degradation to socioeconomic wellbeing of inhabitants of the study area brought about certain remedial actions developed by the residents of the study area. Among such remedial actions, as indicated in Table 3, were use of sand bags, rubbles and stones, and debris/wood logs. However, as much as $56.6 \%$ of the respondents adopted the construction of contours and $36.4 \%$ created water course by digging of channels as a way to drain off the rain run-off. The use of sandbag (Photo 5) by all the surveyed respondents entails the filling of empty bags of cement with sand and have them placed on the path of the run-off, not only as way to control the rate of runoff but also to fill up the cut drenches on the land that resulted from eater erosion.

Table 3. Remedial actions for land restoration in selected urban Abeokuta communities $(n=173)$

\begin{tabular}{|l|c|c|}
\hline \multicolumn{1}{|c|}{ Variables } & Frequency & Percentage \\
\hline Use of sand bags & 173 & 100.0 \\
\hline Use of rubbles and stones & 173 & 100.0 \\
\hline Use of debris/wood logs & 173 & 100.0 \\
\hline Construction of contour & 98 & 56.6 \\
\hline Construction of drainages & 63 & 36.4 \\
\hline
\end{tabular}

Source: own elaboration.

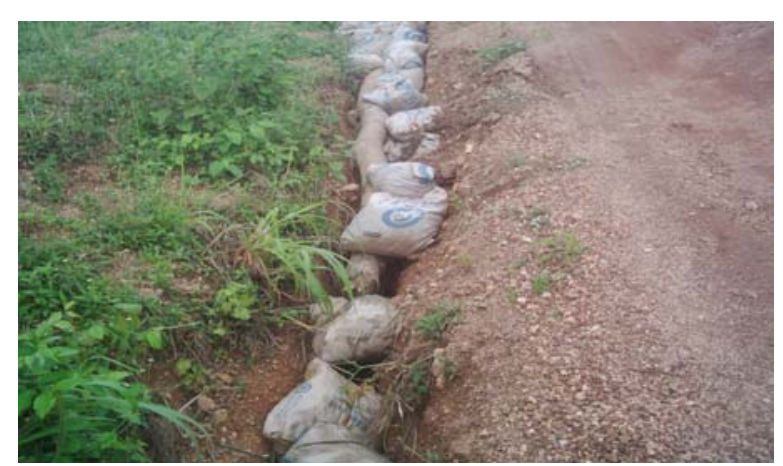

Photo 5. Packs of sand bags as erosion control measures in the study area (phot. O.A. Lawal-Adebowale)

On a similar note was use of debris and wood logs by all the surveyed residents of the study area. This remedial action entails the collection of grasses and wood trunks to fill up cut drenches or degraded land surface with a view to restoring the degraded land for the benefit of the community members. This remedial action, as indicated by GHOLAMI et al. [2014], has conservation effects on land use for sustenance, whereby it controls the impact of plash erosion, rate of runoff, sediment concentration, soil loss- es, and enhances infiltration. Alternative to this was the construction of contours by some $(56.6 \%)$ of the residents by heaping up the top soils for preventing the subsequent run-off from further wearing of the land surface whenever it rains. The use of these aforementioned materials as remedial action of land restoration cannot be unconnected with the fact that they were often gotten at little or no cost [LAWAL-ADEBOWALE, AROMOLARAN 2015] thereby accounting for regular use of the materials for water erosion control and land restoration. The remedial action of land restoration at little or cost is termed passive restoration action by GAO and LIU [2010].

Use of rubbles and stones were also found as useful remedial action for land restoration among all the respondents. This entails sourcing of scraped asphalts from reconstructed roads and quarried stoned to fill up cut drenches and developed gullies as a result of water erosion. Unlike the sandbags usage which costs little or no monetary investment, sourcing of scraped asphalts and quarried stones were usually at a financial cost thus accounting for collective efforts for financial contributions among residents of the area. In the same vein was the construction of drainage, though by a few $(36.4 \%)$ of the surveyed residents of the study area. This remedial action for land restoration entails the use of bricks and cement for construction of water channels for the purpose of draining off the thrust of moving water whenever it rains. This remedial action is often carried out by individuals whose income is above what the average societal members earns either monthly or annually. Unlike the passive remedial action or materials acquired at little or no cost for control of land degradation, the active remedial action such as sourcing of scraped asphalts and quarried stones, and drainage construction requires heavy human intervention and financial investment to restore degraded land [GAO, LIU 2010]. The active remedial action, as indicated by JIANG et al. [2006], which may take the form of mechanical, biological, ecological, and engineering actions, employs varied procedure to achieve effective land rehabilitation.

\section{EFFECTIVENESS AND SUSTAINABILITY OF THE EMPLOYED REMEDIAL ACTIONS FOR LAND RESTORATION}

The employed remedial actions for land restoration by residents of the study area must have been borne out of the expectation for effective control of varying forms of land degradation experienced in their environment. The extent to which restoration of the degraded land is achieved thus determines the effectiveness of the employed remedial actions. In view of this, interactions with the residents of the surveyed environment, as indicated in Table 4, shows that the use of sand bag, as expressed by $76.9 \%$ of them, effected the expected restoration by reducing the rate of run-off and holding the moving soil in place, filling up the cut drenches on the land surface and as such 
Table 4. Effectiveness of the employed remedial actions for land restoration $(n=173)$

\begin{tabular}{|l|l|c|c|}
\hline \multicolumn{1}{|c|}{ Variables } & \multicolumn{1}{|c|}{ Restoration effects } & $\begin{array}{c}\text { Fre- } \\
\text { quency }\end{array}$ & $\begin{array}{c}\text { Percent- } \\
\text { age }\end{array}$ \\
\hline $\begin{array}{l}\text { Use of sand } \\
\text { bags }\end{array}$ & $\begin{array}{l}\text { reduced the rate of run-off, } \\
\text { hold the soil in place, filled up } \\
\text { the cut drenches and makes the } \\
\text { road passable }\end{array}$ & 133 & 76.9 \\
\hline $\begin{array}{l}\text { Use of rubbles } \\
\text { and stones }\end{array}$ & $\begin{array}{l}\text { slow down the run-off, hold } \\
\text { the soils in between rubbles, } \\
\text { prevents water logging, makes } \\
\text { the road passable }\end{array}$ & 169 & 97.7 \\
\hline $\begin{array}{l}\text { Use of debris/ } \\
\text { wood logs }\end{array}$ & $\begin{array}{l}\text { slows down the runoff, par- } \\
\text { tially holds the soil in place }\end{array}$ & 98 & 56.6 \\
\hline $\begin{array}{l}\text { Construction } \\
\text { of contours }\end{array}$ & $\begin{array}{l}\text { slows down the rate of run-off, } \\
\text { partially holds the soil in place, } \\
\text { brings about diversion of run- } \\
\text { off elsewhere, prevents rill } \\
\text { erosion from escalating to } \\
\text { gully erosion }\end{array}$ & 61 & 35.3 \\
\hline $\begin{array}{l}\text { Construction } \\
\text { of drainages }\end{array}$ & $\begin{array}{l}\text { channel out the run-off, pre- } \\
\text { vents flooding and degradation } \\
\text { of the land, makes the road and } \\
\text { terrains passable, prevents } \\
\text { destruction structures closed } \\
\text { up cut drenches }\end{array}$ & 173 & 100 \\
\hline
\end{tabular}

Source: own elaboration.

made the degraded land passable for both human and vehicles.

Use of debris and wood logs, as indicated by $56.6 \%$ of the respondents, helps to fill up cut drenches on land surface alongside reducing the rate of runoff. This is in line with Wu et al. [2012], GHOLAmI et al. [2013] submission that use of debris, particularly plant debris or grasses reduce erosion rates and enhance infiltration. Field observation and interactive discussion with the surveyed residents of the study area showed that this remedial action does not make easy-passage for both humans and vehicles possible because the used materials hardly allowed for levelled surface. In addition, while the (heavy) wood log helps to hold the soil in place during the runoff, the grasses are readily washed off whenever it rains. Constructed contours, as indicated by $35.0 \%$ of the respondents, which merely slowed down the thrust of run-off, were actually used for diverting the run-off elsewhere thereby preventing further wear and tear of the land surface, and for preventing rill erosion from escalating to gullies.

Usage of rubbles and stones serves useful purpose in the quest for restoration of degraded land. As indicated by $97.7 \%$ of the surveyed residents of the study area, this remedial action of land restoration brought about the reduction of the rate of runoff, holds the soils in between rubbles, prevents water logging, and makes the road passable (Photo 6). In the same vein, drainage construction were believed by all the residents of the study area to be an effective remedial action of land restoration on the ground that it functions as a near-perfect erosion control or elimination mechanism by out rightly channelling out the run-off, and as such prevents flooding and water logging. Consequently, this action not only makes the road and

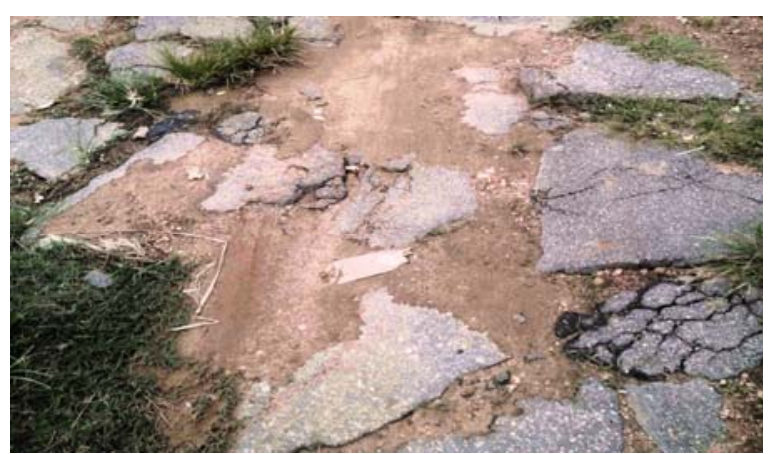

Photo 6. Usage of rubbles for filling up drenches for restoration of degraded land (phot. O.A. Lawal-Adebowale)

terrains passable, it prevents destruction of structures and makes the environment habitable.

\section{SUSTAINABILITY OF THE EMPLOYED REMEDIAL ACTIONS FOR LAND RESTORATION}

Consideration of the employed remedial actions of land restoration for sustainability (Tab. 5) in the study area shows that sandbag usage, as indicated by $79.8 \%$ of the respondents was moderately sustainable. This was based on the fact that the bags got torn over time thereby exposing the sand content to nature; and with time, this becomes eroded by rain runoff. In line with this submission was the observation that a prolonged use of the sand bags results in tear wear of the bags due to weakness of the bags. As shown in Photo 5 , sand bags, which remain outstanding among all other remedial mechanisms undertaken by the residents of the study area, are however sustainably used by promptly replacing the weak bags as soon as they worn out; else, the exposed sand content of the bags become quickly eroded.

Table 5. Sustainability of the employed remedial actions for land restoration $(n=173)$

\begin{tabular}{|l|c|c|c|}
\hline $\begin{array}{c}\text { Sustainability of land } \\
\text { degradation control meas- } \\
\text { ures }\end{array}$ & Sustainable & $\begin{array}{c}\text { Moderately } \\
\text { sustainable }\end{array}$ & $\begin{array}{c}\text { Not } \\
\text { sustainable }\end{array}$ \\
\hline Use of sand bags & $33(19.1)^{*}$ & $138(79.8)$ & $2(1.1)$ \\
\hline Use of rubbles and stones & $141(81.5)$ & $32(18.5)$ & 0 \\
\hline Use of debris/wood logs & 0 & $63(36.4)$ & $110(63.6)$ \\
\hline Construction of contours & 0 & $37(21.4)$ & $136(78.6)$ \\
\hline Construction of drainages & $173(100)$ & 0 & 0 \\
\hline
\end{tabular}

* \% in parenthesis.

Source: own elaboration.

On another note, both the use of rubbles and stones, and drainage construction were found sustainable by $81.5 \%$ and $100 \%$ of the surveyed residents respectively. The emphasis by all the respondents that drainage construction was sustainable was borne out of the fact that the remedial action appropriately channel out runoff whenever it rains thereby preventing degradation of the land area. Field observation in this regard shows that the drainage construction, which is often made of bricks and cement, becomes 
durable and remains permanent as water course for draining out rain runoff. The use of rubbles and stones were equally observed to be sustainable as the materials hold the soil in place such that it could not be easily eroded (Photo 6). As part of the field observation, rain runoff readily flows over the rubbles with little or no removal of the soil.

As much as $63.5 \%$ and $78.6 \%$ of the respondents however respectively found the use of contour construction and, usage of debris and wood logs unsustainable on the ground that these remedial actions for land restoration do not really restore the degraded land but only reduce the rate of runoff and prevent further degradation of the degraded land. In reality, these remedial actions were not durable enough as the used materials for erosion control were readily washed off in the trend of heavy thrust of runoff.

\section{CONCLUSION AND RECOMMENDATIONS}

In view of the study outcome, it could be concluded that land degradation remains a serious issue in some parts of urban communities in Abeokuta division of Ogun State, Nigeria. Such degradation, brought about by interactive environmental factors, took the form of land erosion, water logging, land compaction, flooding, loss of soil cover and series land pores or potholes. The resultant effects of land degradation in the study area included wear and tear of the open lands, destruction of roadways and structures, hindrance of human and automobile mobility, threats to inhabitation and their socioeconomic growth. Commonly employed control measures for stemming the tide of land degradation by the residents of the selected communities were use of sandbags, rubbles and stone, debris and wood log, construction of contours and to some extent, drainages. Among these control measures, drainage construction was empirically observed to be the most effective and sustainable land degradation control measures in the study area. Given the destructive impacts of land degradation on man's social and economic endeavours, it becomes essential for affected residents of Abeokuta urban communities to become pro-active by taken degradation preventive actions, particularly in terms of ensuring good land use and drainage construction, rather than post-degraded actions which is much more expensive than the degradation preventive actions.

\section{REFERENCES}

ANISHA N.F., Hossain S. 2014. A case study on water logging problems in an urban area of Bangladesh and probable analytical solutions. 2nd International Conference on Advances in Civil Engineering. 26-28 December, 2014 CUET, Chittagong, Bangladesh p. 1-6.

BHANDARI G. 2013. Bio-physical and socio-economic indicators related to land degradation: A case study of $\mathrm{Ru}-$ pandehi district in Nepal. Academia Journal of Agricul- tural Research. Vol. 1. Iss. 12 p. 227-235. DOI: org/10. 15413/ajar.2013.0154.

Catro-Filho C., Cochrane T.A., Norton L.D., CavigLIONE J.H., JOHANSSON L.P. 2001. Land degradation assessment: Tools and techniques for measuring sediment load. 3rd International Conference on Land Degradation and Meeting of the IUSS Subcommission C - Soil and Water Conservation. September 17-21, 2001. Rio de Janeiro, Brazil. p. 1-20.

CMA undated. Soil erosion solutions: Helping North Coast landholders reduce soil erosion [online]. NSW DPI Wollongbar. Catchment Management Authority. [Access 29.10.2015]. Available at: http://www.dpi.nsw.gov. au/agriculture/resources/ soils/erosion

CORBIN J., STRAuSS A. 2008. Basics of qualitative research: Techniques and procedures for developing grounded theory. Thousand Oaks, CA. SAGE Publications. ISBN 978-1412906449 pp. 400.

ECan 2007. Erosion and sediment control principles and procedures. Part B. In: Erosion and Sediment Control Guide Environment Canterbury [online]. [Access 22.06.2015]. Available at: http:www.crc.govt.nz/ publications/General/PartB3_UnderstandingErosion Sedimentation.pdf

FranCis G.S., TABLEY F.J., White K.M. 2001. Soil degradation under cropping and its influence on a weekly structured New Zealand silt loam soil. Australian Journal of Soil Research. Vol. 39. No 2 p. 297-305.

GAO J., LiU Y. 2010. Determination of land degradation causes in Tongyu County, Northeast China via land cover change detection. International Journal of Applied Earth Observation and Geoinformation. Vol. 12 p. 9-16.

Gholami L., Banasik K., SAdeghi S.H., Khaledi DarVisHAN A., HEJDUK L. 2014. Effectiveness of straw mulch on infiltration, splash erosion, runoff and sediment in laboratory conditions. Journal of Water and Land Development. No. 22 p. 51-60. DOI: 10.2478/ jwld-20140022 .

Gholami L., Sadeghi S.H.R., Homaee M. 2013. Straw mulching effect on splash erosion, runoff and sediment yield from eroded plots. Soil Science Society of America Journal. Vol. 77 p. 268-278.

GREPPERUD S. 1996. Population pressure and land degradation: The case of Ethiopia. Journal of Environmental Economics and Management. Vol. 30. Iss. 1 p. 18-33.

IDAh P., Musa J. J., Mutapha H. I., ARUgungu M.M. 2009. An investigation into the causes of water logging at Zauro Polder Pilot Project Scheme in Birnin Kebbi, Nigeria. AU Journal of Technology. Vol. 13. Iss. 2 p. 95100.

IFPRI 2011. The economics of desertification, land degradation and drought: Toward an integrated global assessment. IFPRI Discussion Paper 01086. International Food Policy Research Institute/Zentrum für Entwicklungsforschung. Washington, DC/Bonn pp. 173.

JiAng D., Zong W., Li X., LiU Z., Yan Q., He S. 2006. Rehabilitation of desertified lands in Western Horqin steppe. Chinese Journal of Ecology. Vol. 25. Iss. 3 p. 243-248.

JONES H. 2014. Visual methodologies: Using images in social research. Slide presentation on Qualitative Methods in Social Research pp. 21.

Junge B., Dercon G., Abaidoo R., Chikoye D., Stahr K. 2008. Estimation of medium-term soil redistribution rates in Ibadan, Nigeria, by using the $137 \mathrm{Cs}$ technique. [International Research on Food Security, Natural Re- 
source Managementand Rural Development]. [October 7-9 2008 Tropentag, University of Hohenheim].

Lawal-Adebowale O.A., Aromolaran K.A. 2015. Indices of land degradation and control measures in selected urban communities of Abeokuta, Ogun State, Nigeria. International Journal of Social Ecology and Sustainable Development. Vol. 6. Iss. 4 p. 54-66.

MACAUlay B.M. 2014. Land degradation in northern Nigeria: The impacts and implications of human-related and climatic factors. African Journal of Environmental Science and Technology. Vol. 8. Iss. 5 p. 267-273.

Massachusetts Nonpoint Source Pollution Management (undated). Land reclamation [online]. pp. 2. [Access 4.02.2016]. Available at: http://projects.geosyntec.com/ npsmanual/Fact\%20Sheets/Land\%20Reclamation.pdf

MichAel A.M., OJHA T.P. 2006. Principles of agricultural engineering. Vol. II. 5th ed. New Delhi. M/S Jain Brothers p. 391-457.

Nkwi P., Nyamongo I., Ryan G. 2001. Field research into socio-cultural issues: Methodological guidelines. Yaounde, Cameroon. International Centre for Applied Social Sciences, Research, and Training/UNFPA. ISBN 9956140023 pp. 95.

Nkonya E., Gerber N., von Braun J., de Pinto A. 2011. Economics of land degradation: The costs of action versus inaction. International Food Policy Research Institute (IFPRI). Brief 68.

Nkonya E., Gicheru P., Woelcke J., OKoba B., Kilambya D., GACHIMBI L.N. 2008. On-site and off-site long-term economic impacts of soil fertility management practices. IFPRI Discussion Paper 778. Washington, DC: International Food Policy Research Institute pp. 24.

OECD 2007. Glossary of statistical terms [online]. Paris. Organisation for Economic Co-operation and Development pp. 863. [Access 2.11.2015]. Available at: http://ec.europa.eu/eurostat/ramon/coded_files/OECD_g lossary_stat_terms.pdf

Ogboi E., NMOR E. 2013. Land degradation in Delta State, Nigeria: Forms and causes. Journal of Science and Multidisciplinary Research. Vol. 5. Iss. 2 p. 176-182.

SAFRIEL U.N. 2007. The assessment of global trends in land degradation. In: Climate and land degradation. Eds M.V. Sivakumar, N. Ndiang'ui. Berlin, Heidelberg, Germany. Springer-Verlag p. 1-38.

SKoupy J. 1987. Desertification in Africa: Agricultural and meteorological program. [Regional training seminar on drought and desertification in Africa]. [Addis Ababa]. WMO p. 33-45.

The State of Queensland 2011. Understanding floods: Questions \& answers [online]. [Access 16.01.2016]. Available at: www.chiefscientist.qld.gov.au
The World Bank 2016. Population growth (annual \%) [online]. [Access 11.01.2016]. Available at: http://data. worldbank.org/indicator/SP.POP.GROW

TowHID K.G. 2004. Causes and effects of water logging in Dhaka city, Bangladesh, TRITA-LWR. Master thesis. Stockholm. Royal Institute of Technology. Department of Land and Water Resource Engineering pp. 63.

Trading Economics 2016. Population growth (annual \%) in Nigeria [online]. [Access 09.10.2015]. Available at: http://www.tradingeconomics.com/nigeria/populationgrowth-annual-percent-wb-data.html

Turkelboom F., Wangchuk T., Tenzin K. 2001. Land degradation assessment in a farming system perspective: the case of Eastern Bhutan. Ministry of Agriculture, Thimphu, Bhutan.

UNCCD 2012. Zero net land degradation: A sustainable development goal for Rio+20: To secure the contributions of our planet's land and soil to sustainable development, including food security and poverty eradication [online]. Bonn. United Nations Convention to Combat Desertification pp. 28. [Access 21.01.2016]. Available at: http://www.unccd.int/Lists/SiteDocumentLibrary/ Rio+20/UNCCD_PolicyBrief_ZeroNetLandDegradation. pdf

UNCHS 2001. State of the world's cities 2001. Nairobi. United Nations Centre for Human Settlements.

UNEP 2002. State of the Environment and Policy Retrospective: 1972-2002: Urban areas [online]. United Nations Environment Programme p. 240-269. [Access 07.03.2016]. Available at: http://web.unep.org/geo/sites/ unep.org.geo/files/documents/chapter2-8_urban.pdf

USEPA 2002. Best management practices to reduce nonpoint source pollution in the town of Plainfield, Connecticut. American Groundwater Trust. Boston, MA.

VLeK P.L., LE Q.B., TAMENE L. 2008. Land decline in landrich Africa: A creeping disaster in the making. Rome. Consultative Group on International Agricultural Research, Science Council Secretariat pp. 55.

WOLKOWSKI R., LOWERY B. 2008. Soil compaction: Causes, concerns and cures [online]. University of Wisconsin Cooperative Extension pp. 8. [Access 04.02.2016]. Available at: http://www.soils.wisc.edu/extension/pubs/ A3367.pdf

Wu L., LONG T.Y., LiU X., MMEREKi D. 2012. Simulation of soil loss processes based on rainfall runoff and the time factor of governance in the Jialing River Watershed, China. Environmental Monitoring and Assessment. Vol. 184. Iss. 6 p. 3731-3748. DOI: 10.1007/s10661-0112220-6.

\section{Okanlade Adesokan LAWAL-ADEBOWALE}

\section{Skuteczność i trwałość działań zmierzających do rekultywacji ziemi w obszarach miejskich Abeokuta, stan Ogun, Nigeria}

\section{STRESZCZENIE}

Destrukcyjny wpływ degradacji ziemi na socjalne i ekonomiczne przedsięwzięcia mieszkańców niektórych obszarów miejskich w Abeokuta w stanie Ogun w Nigerii wymaga podjęcia działań naprawczych w celu przywrócenia odpowiedniej jakości przekształconym obszarom. Jest to ważne ze względu na bezpieczeństwo i więk- 
sze społeczno-ekonomiczne zaangażowanie mieszkańców. Działania naprawcze podjęte w tym zakresie obejmowały użycie worków z piaskiem, gruzu, kłód drewnianych i kamieni oraz tworzenie spadków i budowę drenaży. Choć każda z tych akcji w jakiś sposób wydajnie polepsza jakość zdegradowanej ziemi, stwierdzono, że użycie gruzu i kamieni oraz budowa konstrukcji drenarskich były odpowiednie do rekultywacji ziemi na tym obszarze, pod warunkiem że działania te nie doprowadzą do wysycenia ziemi wodą lub do zalania terenu. Zalecono jednak, aby działania naprawcze były raczej podejmowane w celu zapobiegania degradacji ziem niż ich rekultywacji, ponieważ dużo taniej jest zapobiegać degradacji niż rekultywować już zdegradowane tereny.

Słowa kluczowe: degradacja ziemi, działania naprawcze, obszary miejskie, przyczyny, skuteczność, trwałość 